\title{
PARADA CARDIORRESPIRATÓRIA (PCR)
}

\author{
CARDIAC ARREST \\ Antônio Pazin-Filho ; José Carlos dos Santos²; Renato Barroso Pereira de Castro²; \\ Cláudia Dizioli Franco Bueno ${ }^{2 \&}$ André Schmidt ${ }^{1}$

\begin{abstract}
'Docentes. Departamento de Clínica Médica. Faculdade de Medicina de Ribeirão Preto -USP. ${ }^{2}$ Médicos Assistentes. Hospital das Clínicas da Faculdade de Medicina de Ribeirão Preto -USP. CorResPondência: Prof. Dr. Antonio Pazin Filho. Centro de Estudos de Emergências em Saúde. Unidade de Emergência - HCFMRP-USP. Rua Bernardino de Campos, 1000. CEP: 14015-030 - Ribeirão Preto - SP. e-mail: apazin@fmrp.usp.br
\end{abstract}

PAZIN FILHO A; SANTOS JC; CASTRO RBP; BUENO CDF \& SCHMIDT A. Parada cardiorrespiratória (PCR). Medicina, Ribeirão Preto, 36: 163-178, abr./dez. 2003.

RESUMO - São revisados os princípios do atendimento da parada cardiorrespiratória, enfatizando a importância do suporte básico de vida e a conduta diferenciada na dependência dos três principais tipos de parada: fibrilação/taquicardia ventricular, assistolia e atividade elétrica sem pulso. Discutem-se os cuidados pós-reversão, a serem implementados, e sua importância na sobrevida.

UNITERMOS - Parada Cardíaca. Ressuscitação Cardiopulmonar. Fibrilação Ventricular. Cuidados Pós-ressuscitação.

\section{1- INTRODUÇÃO}

A PCR é situação dramática, responsável por morbimortalidade elevada, mesmo em situações de atendimento ideal. Na PCR, o tempo é variável importante, estimando-se que, a cada minuto que o indivíduo permaneça em PCR, $10 \%$ de probabilidade de sobrevida sejam perdidos (Figura 1). O treinamento dos profissionais de saúde no atendimento padronizado dessa situação clínica pode ter implicações prognósticas favoráveis.

Variáveis são os contextos em que a PCR pode se apresentar. No plano hospitalar, pode-se prever desde ocorrências em locais menos equipados, como ambulatórios, até as que surgem em outros, muito bem equipados, como as unidades de terapia intensiva e as unidades coronarianas. No entanto, a PCR é mais comum no ambiente pré-hospitalar, fato exemplificado pelo dado histórico de que cerca de $50 \%$ dos pacientes com infarto agudo do miocárdio não chegam vivos ao hospital.
A etiologia da PCR é variável, de acordo com a idade. Neste texto, será apresentado o atendimento da PCR no adulto, salientando-se as diferenças no atendimento de crianças e lactentes.

\section{2 - DIAGNÓSTICO DA PCR}

O diagnóstico deve ser feito com a maior rapidez possível e compreende a avaliação de três parâmetros: responsividade, respiração e pulso (Figura 2).

A responsividade deve ser investigada com estímulo verbal e tátil. O estímulo verbal deve ser efetuado com voz firme e em tom alto, que garanta que a vítima seja capaz de escutar o socorrista. O estímulo tátil deve ser firme, sempre contralateral ao lado em que se posiciona o socorrista, para evitar que o mesmo seja agredido, involuntariamente, por pacientes semiconscientes.

Se não houver resposta, considera-se que a vítima esteja em situação potencialmente letal, devendo ser assegurado atendimento médico de emergência. Esse conceito dá suporte ao chamado por ajuda. 


\section{Importância da Desfibibrilação Precoce}

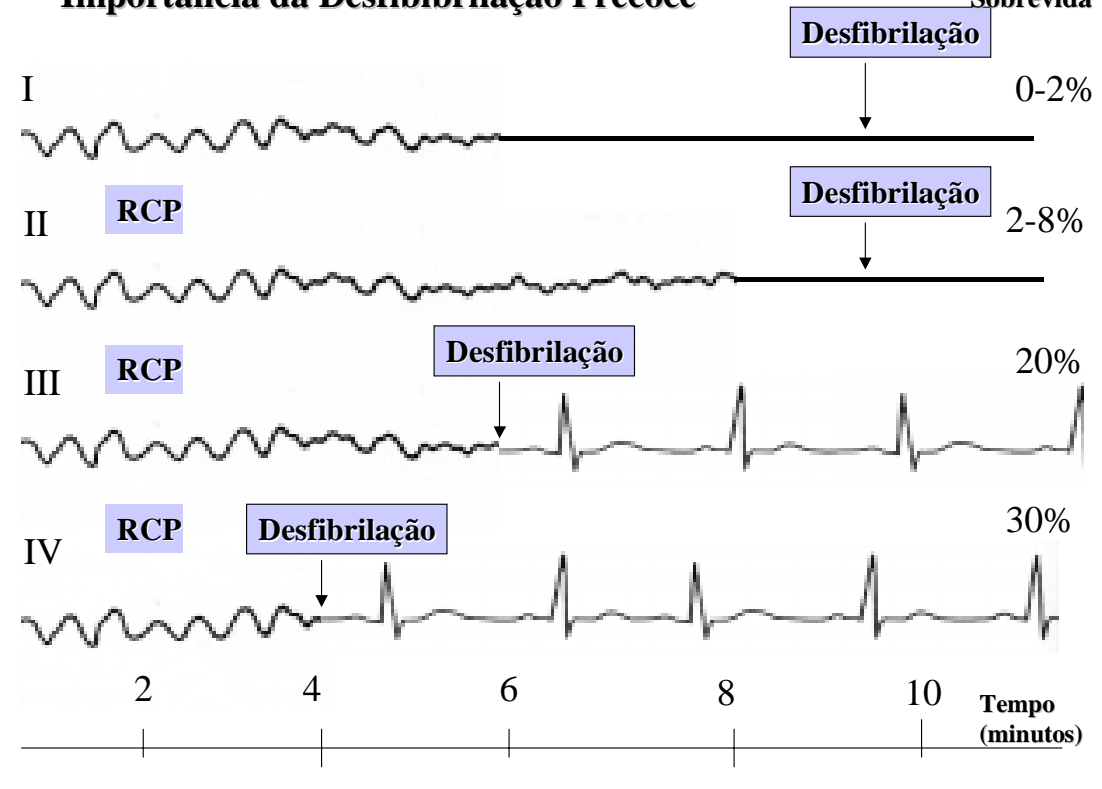

Figura 1 - Importância da rapidez do atendimento, na sobrevida de pacientes com PCR.

Exemplo de quatro situações de PCR, variando as condições de atendimento, oferecidas em função do tempo.

I - Paciente não recebe ressuscitação cardiopulmonar (RCP). Recebe desfibrilação com aproximadamente 10 min de evolução da PCR, já em assistolia.

II - Paciente recebe RCP precoce, porém a desfibrilação permanece tardia.

III e IV - À medida em que se garante RCP e a desfibrilação se torna mais precoce no atendimento, as chances de sobrevida aumentam.

Adaptado de Cummins RO; Suporte Avançado de Vida em Cardiologia, 1997. Desfibrilação, pg 4-2.

\section{Suspeita de PCR}

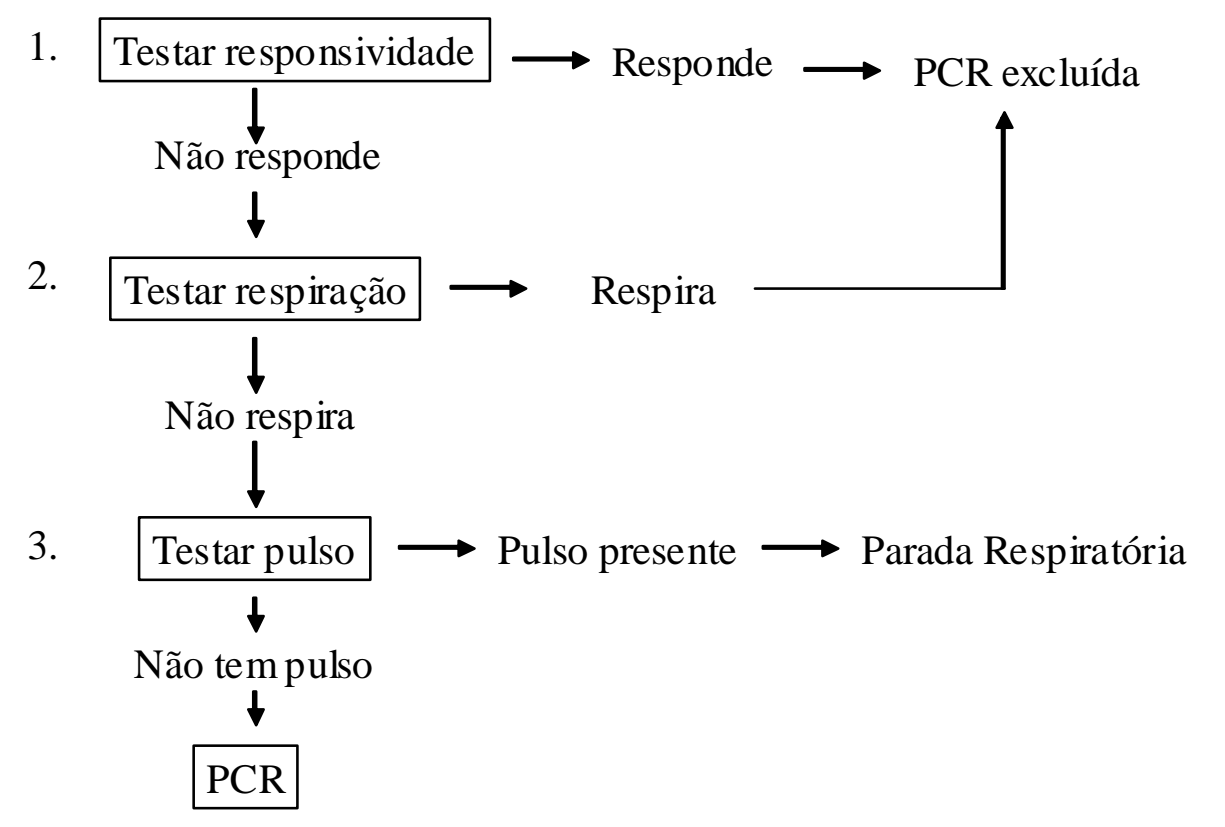

Figura 2 - Diagnóstico inicial da PCR 
O pedido de ajuda inclui a solicitação de desfibrilador e de suporte avançado de vida. O preenchimento desses dois quesitos é variável, dependendo do contexto (pré ou intra-hospitalar) da PCR. No adulto, o pedido de ajuda deve ter prioridade sobre o atendimento da vítima, significando que se o socorrista estiver sozinho, deve abandonar a vítima e acionar o sistema de emergência. Tal recomendação está embasada no fato de o único tratamento disponível para a principal causa de PCR, no adulto, constituir-se no desfibrilador (vide item específico). Já, na criança e no lactente, como a principal causa é hipóxia, o pedido de ajuda deve suceder o suporte ventilatório, inicial. No contexto pré-hospitalar, o pedido de ajuda deve ser o mais claro possível. Quando se solicitar a um leigo que busque ajuda, deve-se deixar claro o que se espera que ele consiga. A "ajuda", para o leigo, pode ser o policial ou o segurança e não a ativação do serviço de urgência. Ainda, no contexto pré-hospitalar, quando se solicitar ajuda, numa situação em que existam várias pessoas presentes, deve-se designar uma pessoa em específico, para se garantir que o serviço de urgência tenha sido acionado. Não se designar uma pessoa pode implicar que ninguém vá solicitar ajuda, inferindo que outra pessoa já tenha ido acionar o sistema de urgência. Quando se tratar de solicitação de ajuda por telefone, uma regra importante a ser seguida é que o solicitante inicie a conversa telefônica, mas quem deve interrompê-la é o responsável pelo sistema de urgência, o que garante que a ligação só será interrompida, quando todas as informações necessárias tiverem sido conseguidas.

Após a ativação do serviço de urgência, procede-se à verificação da respiração. A vítima inconsciente apresenta relaxamento da musculatura da base da língua, que cai sobre a entrada da via aérea, o que implica que toda vítima inconsciente tem a via aérea obstruída. Além desse fator, outros, como corpos estranhos, edema das vias aéreas ou secreções, podem contribuir para a obstrução das vias aéreas. Frente a esse conhecimento, a primeira providência para se testar a respiração é a manobra de desobstrução das vias aéreas. Existem duas manobras básicas para isso: hiperextensão da cabeça e elevação do mento, ou elevação da mandíbula. Ambas são eficazes, embora a primeira seja proibitiva na possibilidade de trauma cervical.

Após a abertura das vias aéreas, o socorrista deve aproximar o rosto da face da vítima e VER se há expansão do tórax, OUVIR se há eliminação de ar pelas vias aéreas e SENTIR se o fluxo expiratório vai de encontro ao seu próprio rosto. Se houver respiração efetiva, não se trata de PCR, sendo provável que outras causas de depressão de nível de consciência estejam presentes. Deve-se aguardar a chegada do serviço de urgência junto à vítima, atento ao seu padrão respiratório. Caso não seja detectada respiração efetiva, a permeabilidade das vias aéreas deve ser investigada, no intuito de descartar a possibilidade de corpo estranho obstruindo a via aérea inferior, não visível à inspeção da cavidade oral. Procede-se à realização de duas ventilações de resgate, que podem ser efetuadas por respiração boca-a-boca ou através de dispositivo bolsa-valva-máscara, no ambiente hospitalar. Na eventualidade de não se obter expansão do tórax, deve-se repetir a manobra de desobstrução das vias aéreas e tentar novamente, porque a parada respiratória por corpo estranho é rara no adulto. Geralmente, em tais casos, o contexto da PCR sugere a etiologia, como por exemplo, a PCR em churrascarias, (obstrução por pedaços de carne). Comprovada a existência de corpo estranho, deve-se realizar a manobra de Heimliche, consistindo em compressões ascendentes na região epigástrica da vítima. $\mathrm{Na}$ maioria dos casos, a expansão do tórax será obtida e pode-se passar para o teste do pulso.

O pulso deve ser investigado no sítio carotídeo, por ser o último a desaparecer e o primeiro a ser restabelecido numa situação de instalação e reversão de PCR. Além disso, tem a vantagem da proximidade do socorrista. Dez segundos são suficientes para se comprovar a ausência de pulso, com exceção feita aos pacientes hipotérmicos, para os quais um tempo maior (30 a $40 \mathrm{seg}$ ) pode ser necessário. Caso o pulso esteja presente, trata-se de parada respiratória isolada. Nesse caso, deve-se garantir o suporte ventilatório provisório (boca-a-boca ou bolsa-valva-máscara) até que o acesso definitivo à via aérea (intubação orotraqueal) possa ser providenciado. $\mathrm{Na}$ ausência de pulso, constata-se o diagnóstico de PCR: não-responde, não-respira e não-tem-pulso.

Uma vez constatado o diagnóstico, deve ser reforçado o pedido por ajuda e iniciam-se as manobras de suporte básico de vida.

\section{3 - SUPORTE BÁSICO DE VIDA (SBV)}

O suporte básico de vida compreende ventilação e massagem cardíaca. Deve ser instituído o mais precocemente possível, e só deve ser interrompido em 
três situações: para se proceder à desfibrilação, para a realização da intubação orotraqueal e para a infusão de medicação na cânula orotraqueal.

A ventilação pode ser executada por métodos não assistidos, como a ventilação boca-a-boca, ou com métodos assistidos, ou seja, utilizando-se dispositivos intermediários, como a bolsa-valva-máscara. A ventilação boca-a-boca garante maior volume corrente, enquanto que os métodos indiretos são vantajosos ao garantirem maior aporte de oxigênio. Independente da técnica utilizada, é importante que a ventilação seja realizada na freqüência de 10 a 12 incursões por minuto e com volume em torno de 8 a $10 \mathrm{ml} / \mathrm{kg}$ de peso (na prática, corresponde ao menor volume capaz de expandir o tórax da vítima). Essas precauções visam reduzir a ocorrência de distensão gástrica, regurgitação e aspiração brônquica de conteúdo gástrico.

A massagem cardíaca externa compreende compressões torácicas, realizadas sobre a porção central do esterno. Tais compressões empurram o esterno para o interior do tórax, comprimindo o coração contra a coluna e favorecendo o seu esvaziamento. São capazes de restabelecer apenas 10 a $20 \%$ do débito cardíaco. O socorrista deve posicionar a região hipotenar das mãos sobre o centro do esterno da vítima, com os braços estendidos, e proceder às compressões. O fulcro do movimento deve ser centrado no quadril e não nos cotovelos ou ombros do socorrista. A freqüência de compressões deve ser de 100 por minuto. O emprego da técnica correta de massagem cardíaca externa reduz a ocorrência de fraturas de costela. Devido às calcificações de cartilagens costocondrais, comuns em pessoas de faixa etária mais avançada, na qual a PCR é mais frequiente, apesar de o risco ser reduzido com o emprego de técnica correta, ele não é totalmente eliminado. Técnica correta também aumenta a eficácia da massagem e torna o procedimento menos cansativo para o socorrista, aumentando sua capacidade de realizá-lo. A eficácia da massagem pode ser avaliada pela palpação de pulsos arteriais centrais (femoral ou carotídeo) concomitantemente às manobras.

Ao se intercalar em compressões com ventilação, deve-se obedecer à regra de 15 compressões para cada 2 ventilações.

\section{4 - MODALIDADE DE PCR}

Agora, para se prosseguir no atendimento, após a instituição das manobras de SBV, deve-se ter noção da modalidade de PCR. Existem três modalidades de PCR, sendo que as situações de assistolia e atividade elétrica sem pulso apresentam características muito próximas, permitindo que o atendimento seja resumido em, praticamente, duas situações: fibrilação ventricular e taquicardia ventricular sem pulso, cuja ênfase deve ser a desfibrilação, e assistolia/atividade elétrica sem pulso, caracterizadas por busca de uma etiologia. Tais conceitos são delhados a seguir, e sintetizados na Figura 3.

\section{1- Fibrilação Ventricular/ Taquicardia Ventri- cular sem Pulso (FV/TV sem pulso)}

A principal causa de PCR, no adulto, é a fibrilação ventricular (FV). Esse distúrbio do ritmo cardíaco é ocasionado por mecanismo de reentrada, ocasionando contrações desordenadas e inefetivas das células cardíacas. É o distúrbio do ritmo cardíaco mais comum nos primeiros dois minutos de PCR, no adulto. Evolui, rapidamente, para assistolia, caso não sejam estabelecidas medidas de SBV (Figura 1). O único tratamento disponível para o controle desse distúrbio do ritmo cardíaco é a desfibrilação (vide item específico).

A principal causa de $\mathrm{FV}$, em nosso meio, são as síndromes isquêmicas miocárdicas instáveis (SIMI). As taquicardias ventriculares (TV) podem ocasionar PCR e devem ser tratadas como FV. Neste caso, além das SIMIs, devem ser lembradas as miocardiopatias, como a chagásica.

Não existe base científica que comprove a eficácia de qualquer medicação anti-arrítmica em reverter a FV. As medicações (vide Farmacologia) podem ser utilizadas como auxiliares, facilitadoras para que o estímulo elétrico possa reverter o ritmo para sinusal. Equivale a dizer que não se deve retardar a aplicação de choque para a infusão de medicação.

A FV/TV é a modalidade de PCR de melhor prognóstico ${ }^{(1,2)} \mathrm{e}$, em princípio, os esforços de ressuscitação devem continuar até que o ritmo deixe de ser FV/TV (ou porque reverteu para sinusal, ou porque evoluiu para um ritmo terminal).

\section{2- Assistolia}

\section{NÃO DESFIBRILAR.}

A assistolia corresponde à ausência total de qualquer ritmo cardíaco. É a situação terminal. Evidências cada vez mais contundentes apontam que a identificação de assistolia deva corresponder ao término dos esforços. Frente ao seu caráter sombrio, a 


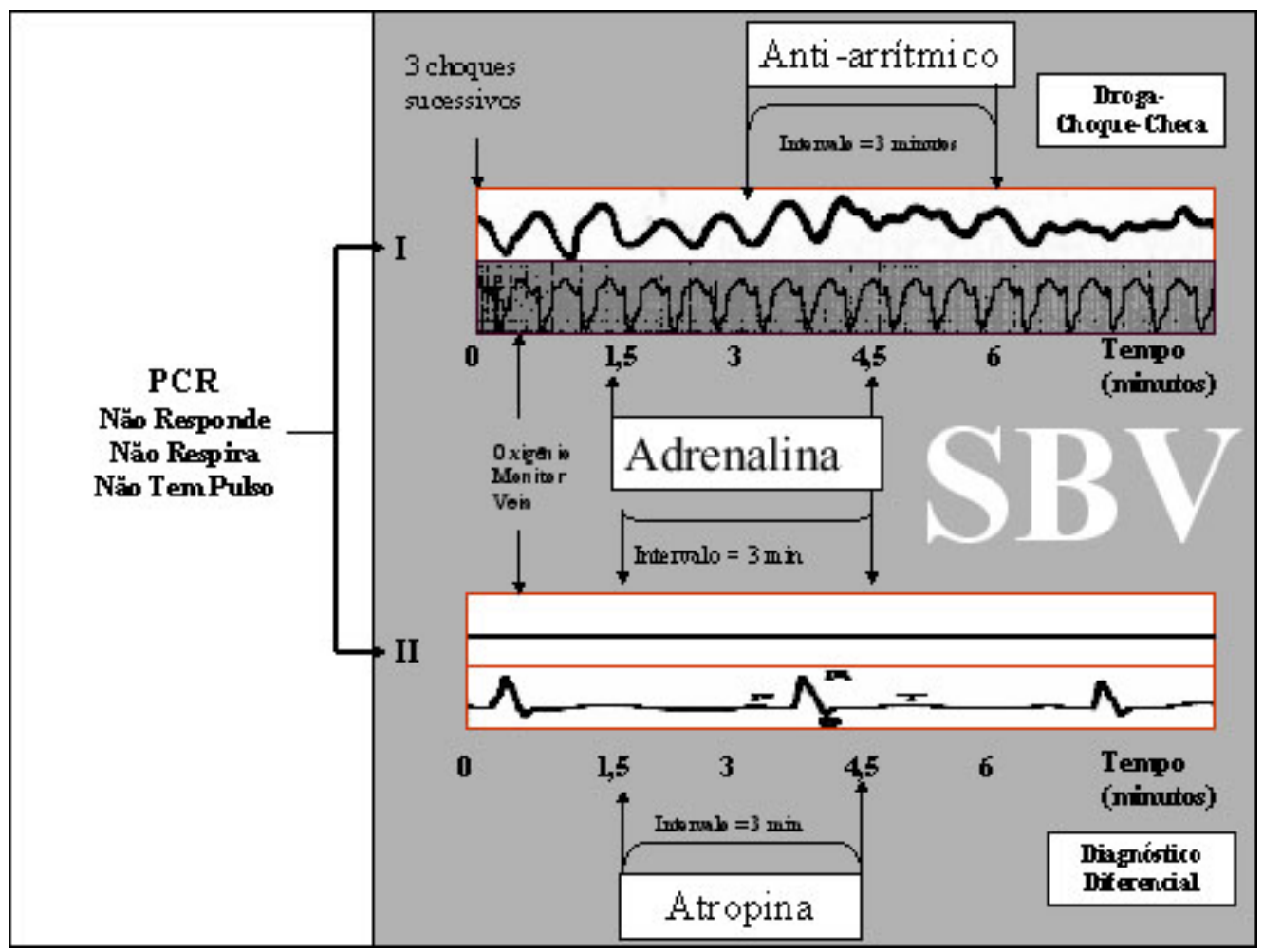

Figura 3 - Demonstra que o atendimento da PCR pode ser resumido em duas situações.

I - Fibrilação Ventricular/Taquicardia Ventricular sem Pulso (FV/TV sem pulso) - caracterizada pelo fato de o único tratamento disponível ser a desfibrilação. Observe que após a deteç̧ão inicial da PCR, o tratamento inicial (tempo 0) são três choques sucessivos. Caso a vítima não apresente reversão para ritmo organizado, caracteriza-se a existência de $\mathrm{FV}$ refratária. Nessa situação, garante-se oxigênio, monitor e veia e SBV, e inicia-se o esquema DROGA-CHOQUE-CHECA, caracterizado pela infusão de uma medicação, aplicação de choque, visando desfibrilação e checagem do pulso para averiguar a reversão. Tal esquema deve persistir até que haja modificação do ritmo para um mais organizado, ou terminal.

II - Assistolia/Atividade Elétrica Sem Pulso (Assistolia/AESP) - caracterizadas por serem ritmos não chocáveis. Nessa situação, o objetivo deve ser o diagnóstico diferencial, buscando causa potencialmente reversível de PCR. Observe que, após o diagnóstico de que não se trata de ritmo chocável, apesar de não serem desferidos choques, também é garantido oxigênio, monitor e veia e SBV.

Observe que a ADRENALINA é a primeira medicação a ser feita em qualquer situação de PCR. Ela não apresenta dose máxima e deve ser feita por via endovenosa ou endotraqueal, enquanto persistirem os esforços, em doses fixas (1mg EV; $2 \mathrm{mg}$ endotraqueal).

Os Antiarrítmicos só são utilizados na FV/TV sem pulso, enquanto a Atropina é exclusiva da Assistolia/AESP, em situações com freqüência cardíaca menor que $60 \mathrm{bpm}$.

Qualquer medicação utilizada (adrenalina, atropina ou anti-arrítmico) exige intervalo de 3 min entre as dosagens. Na situação de FV/TV sem pulso, pode-se realizar a entreposição das doses, como ilustrado.

instituição de manobras de ressuscitação, em pacientes terminais, que apresentem PCR em assistolia, é, cada vez mais, considerada fútil. Em países desenvolvidos, já se considera o desejo dos pacientes com doenças degenerativas incapacitantes ou em estágio terminal de não serem ressuscitados, na eventualidade de PCR. Tais pacientes geralmente, portam uma identificação em pulseiras ou em carteiras (DNR - "DO NOT RESUSCITATE" - "NÃO INICIE RESSUSCITAÇÃO”) e a tendência geral é de respeito à decisão.

$\mathrm{O}$ momento de se interromperem os esforços de ressuscitação levanta uma série de considerações éticas. Embora a decisão deva ser individualizada para cada situação, deve-se considerar o término dos esforços quando: 1) o SBV está sendo oferecido de maneira adequada; 2) foi oferecido suporte adequado de oxigênio através de intubação orotraqueal; 3) não se identificou nenhuma causa corrigível; 4) foi identificado que o paciente é portador de uma doença terminal (DNR), o que implica na futilidade das manobras; 5) o ritmo documentado no monitor não deixou de ser assistolia durante todo o atendimento.

A principal causa de assistolia é a hipóxia, o que justifica as ofertas de oxigênio e ventilação efetivas, como prioritárias no atendimento. Existem outras causas, comuns também para a situação de AESP 
(vide Figura 4), que devem ser procuradas e corrigidas, se identificadas. No entanto, deve-se ter presente que, na situação de assistolia, mesmo a correção dessas causas, geralmente, não implica em resolução da PCR.

O suporte medicamentoso (vide Farmacologia) deve ser instituído, mesmo que as evidências a favor não sejam de alto peso científico.

Pode-se utilizar o marcapasso transcutâneo. Só deve ser tentado no início do atendimento, quando se faz o diagnóstico. Não deve ser utilizado como medida heróica, no decorrer do atendimento, quando todas as outras medidas já foram instaladas. As evidências sobre a efetividade do dispositivo, na situação de assistolia, são pobres.

\section{3 - Atividade Elétrica Sem Pulso (AESP)}

\section{NÃO DESFIBRILAR.}

Sobre o termo AESP, foram agrupados todos os outros possíveis ritmos cardíacos, que podem ser identificados numa PCR, excluídos apenas FV/TV sem pulso e a assistolia. Pode compreender ritmos bradicárdicos ou taquicárdicos, com complexo QRS estreito ou alargado, sinusal, supraventricular ou ventricular. O importante é identificar que, apesar de existir um ritmo organizado no monitor, não existe acoplamento do ritmo com pulsação efetiva (com débito cardíaco). O importante é garantir o SBV e tentar identificar a provável etiologia da PCR. São as mesmas etiologias que devem ser procuradas na assistolia, mas, nesta situação, sua busca deve ser muito mais intensa, pois, somente se uma causa puder ser identificada e corrigida, é que a vítima pode ser retirada da PCR. As possíveis causas para AESP/Assistolia estão listadas de modo mnemônico na Figura 4.

As causas potencialmente corrigíveis de AESP/ Assistolia são: hipovolemia, hipóxia, pneumotórax hipertensivo, hipotermia e tamponamento cardíaco. Causas como acidose pré-existente, distúrbios do potássio e intoxicação são de complexidade intermediária. Já outras causas, como tromboembolismo pulmonar e infarto agudo do miocárdio, são de resolução mais complexa.

A identificação dessas causas deve ser pautada, exclusivamente, pela história fornecida por acompanhantes, sobre as condições em que a vítima foi encontrada, e por dados de exame físico sumário, executado pelo socorrista. Exames subsidiários, como radiografia de tórax, não devem ser utilizados no diagnóstico. Embora alguns procedimentos, como a punção pericárdica ou a drenagem do tórax com agulha, possam parecer agressivos, sendo que o socorrista se sentiria mais confortável em executá-los frente a uma comprovação diagnóstica por exame subsidiário, deve-se lembrar que o tempo para reversão da PCR é exíguo.

Medicações podem assumir papel proeminente em tal situação, como é o caso do bicarbonato de sódio nas situações de hipercalemia, intoxicação por tricíclico ou acidose pré-existente. Como a principal causa de AESP é a hipovolemia, uma prova de volume deve ser tentada, sempre.

\begin{tabular}{ll}
\multicolumn{2}{c}{ Diagnóstico Diferencial - } \\
Diagnóstico & Conduta \\
\hline Hipovolemia & $\begin{array}{l}\text { reposição volêmica } \\
\text { fornecimento de O2 }\end{array}$ \\
Hipóxia & bicarbonato de Na \\
Hipercalemia & aquecimento ativo \\
Hipotermia & bicarbonato de Na \\
$(\mathrm{H}+)$ Acidose preexistente & punção pericárdica \\
Tamponamento cardíaco & drenagem torácica \\
Tensão no Pneumotórax & - \\
Tromboembolismo Pulmonar & bicarbonato de $\mathrm{Na}$ \\
Tóxicos & - \\
Trombo na Coronária (IAM) &
\end{tabular}

Figura 4 - Diagnóstico diferencial em PCR, nas situações de assistolia e AESP.

\section{5- DESFIBRILADOR}

A desfibrilação é constituída pela aplicação de corrente elétrica contínua, no tórax, através do coração, em seu maior eixo, cuja finalidade é promover a despolarização simultânea do maior número possível de células cardíacas. Espera-se que, como o nó sinusal é o primeiro a se despolarizar, ele assuma o comando, quando as células se repolarizarem após a desfibrilação.

Considerando-se a rapidez com que o diagnóstico deva ser feito, os desfibriladores devem ser capazes de monitorizar o ritmo da vítima através de suas pás. Isso permite pronta desfibrilação, caso a FV seja identificada.

A energia fornecida pelos aparelhos varia na dependência do tipo de onda utilizado. Os modelos mais antigos utilizam-se do padrão monofásico, mas a ten- 
dência atual dos fabricantes é que sejam substituídos pelo padrão de onda bifásico, com evidências crescentes $^{(3)}$ de que tal padrão implique em, pelo menos, igual eficácia com menor energia e, presumivelmente, menor dano para o miocárdio. No padrão monofásico, a menor energia eficaz em desfibrilar o miocárdio é 200 Joules. No padrão bifásico, essa energia é menor (em torno de 150 Joules). O conhecimento do tipo de onda com que o desfibrilador trabalha é importante, para evitar seleção de cargas inadequadas no atendimento da PCR. Como ainda não estão identificados em todos os aparelhos, cabe à equipe médica se preocupar em assinalar essa característica. Em nosso meio, as condições econômicas não permitem a troca dos aparelhos com a velocidade apropriada, implicando que os dois tipos de aparelhos possam estar presentes num mesmo serviço.

A desfibrilação só deve ser utilizada na FV/TV sem pulso.

Para que a desfibrilação seja efetiva, o choque deve percorrer o miocárdio em toda a sua extensão, o que depende, em última análise, da impedância torácica (resistência oferecida pelo tórax à passagem da corrente elétrica). A impedância pode ser diminuída pela correta posição das pás, uso de gel condutor, aplicação de pressão sobre as pás e choques sucessivos (Figura 5). Os choques sucessivos são de energia crescente (200-300-360 Joules), quando se utiliza padrão de onda monofásico.

O conceito de desfibrilação precoce, como único tratamento disponível para a FV, fomentou a criação de Desfibriladores Externos Automáticos (DEAs) para levar o recurso ao ambiente pré-hospitalar onde a PCR é mais freqüente. Os DEAs estão se tornando cada vez mais presentes, inclusive por força de legislação, tanto no Exterior como no Brasil. Sua eficácia é comprovada, quando manuseados por pessoas treinadas, mesmo que leigas. Discute-se a sua utilização por leigos não treinados ${ }^{(4)}$.

\section{6- FARMACOLOGIA}

O nível de evidência para qualquer medicação empregada em PCR é baixo.

As medicações devem ser vistas como auxiliares potencialmente úteis, mas não devem interferir ou serem priorizadas em detrimento de medidas de eficácia comprovada (na PCR as duas únicas medidas com tal grau de evidência são o SBV e a desfibrilação para a FV/TV sem pulso).

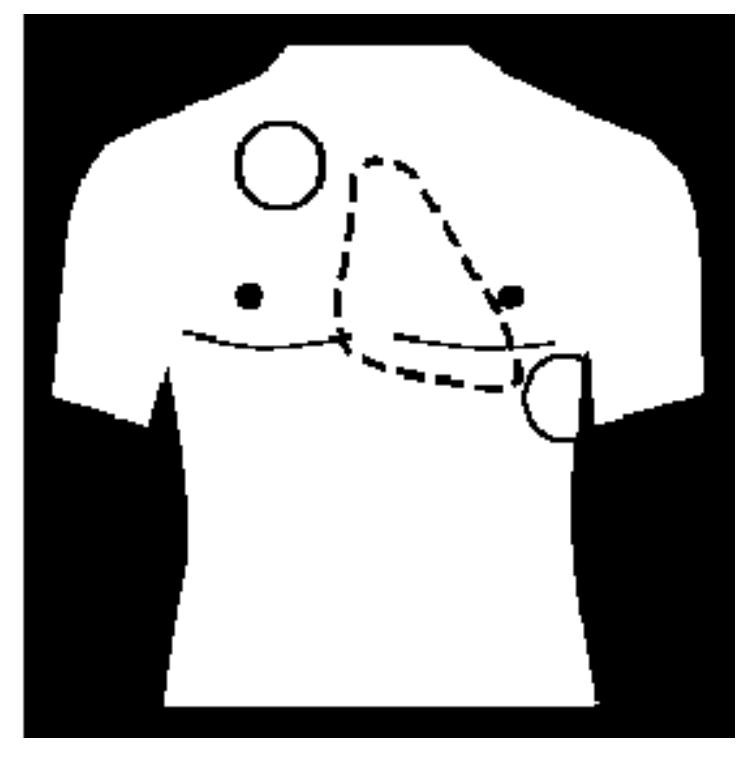

Figura 5 - Desfibrilação

1- Ligue o desfibrilador

2- Aplique gel condutor nas pás e posicione-as adequadamente no tórax do paciente (círculos cheios na figura). Garanta pressão adequada sobre as pás.

3- Selecione o nível de energia apropriado - iniciar com 200 Joules (padrão monofásico $200-300-360$ Joules) ou 150 Joules (padrão bifásico).

4 Garanta que ninguém esteja em contato direto com o paciente e avise a equipe, quando for liberar o choque.

5- Após o choque, verifique o monitor. Caso não haja reversão do ritmo, prossiga para o próximo passo do atendimento.

Toda vez que se optar por uma medicação, deve-se estar atento à sua indicação (quando), mecanismo de ação (porque), farmacocinética (como) e efeitos colaterais (cuidado). A Tabela I apresenta as características para as medicações utilizadas na PCR.

A ausência de circulação efetiva, vigente na PCR, prejudica a chegada de medicações endovenosas ao sistema circulatório central. Deve-se ter este conceito em mente a cada infusão medicamentosa endovenosa, procurando-se otimizar o processo através de infusão de bolus de solução salina $(20 \mathrm{ml})$ e da elevação do braço em que foi infundida a medicação. 
Tabela I - Drogas utilizadas em parada cardiorrespiratória.

\begin{tabular}{|c|c|c|c|c|}
\hline$M E D I C A C ̧ \tilde{A} O$ & QUANDO & СOMO & PORQUE & ATENÇÃ $O$ \\
\hline ADRENALINA & $\begin{array}{l}\text { FV/TV sem pulso } \\
\text { Assistolia } \\
\text { AESP }\end{array}$ & $\begin{array}{l}1 \mathrm{mg} \text { ev em bolus, a cada } \\
3 \text { a } 5 \text { min enquanto durar a } \\
\text { PCR }\end{array}$ & $\begin{array}{l}\text { - Aumenta a pressão de } \\
\text { perfusão }\end{array}$ & $\begin{array}{l}\text { - Doses elevadas, acima } \\
\text { das preconizadas ou em es- } \\
\text { quemas crescentes estão } \\
\text { associadas a maior recu- } \\
\text { peração de circulação es- } \\
\text { pontânea, mas não à alta } \\
\text { hospitalar. }\end{array}$ \\
\hline $\begin{array}{l}\text { AMIODARONA } \\
\text { Apresentação } \\
\text { - } 150 \mathrm{mg} / 3 \mathrm{ml} \text {; } \\
\text { ampolas. }\end{array}$ & FV/TV sem pulso & $\begin{array}{l}\text { Ataque } \\
\text { - PCR - } 300 \mathrm{mg} \text { ev em } \\
\text { bolus seguidos, de } 20 \mathrm{ml} \text { de } \\
\text { SF; considerar } 150 \mathrm{mg} \text { após } \\
15 \mathrm{~min} \text { se não houver re- } \\
\text { versão } \\
\text { - Fora da PCR - } 150 \mathrm{mg} \\
\text { diluído em } 100 \mathrm{ml} \text {, infun- } \\
\text { didos em } 15 \mathrm{~min} \text {; pode-se } \\
\text { repetir a cada } 15 \text { min até } \\
\text { conversão do ritmo. } \\
\text { Manutenção } \\
\text { - } 1 \text { mg/ min nas primeiras } \\
6 \text { h, seguido de } 0,5 \mathrm{mg} / \mathrm{min} \\
\text { nas } 18 \mathrm{~h} \text { consecutivas. } \\
\text { Dose máxima diária } \\
\text { - } 2,2 \text { g. }\end{array}$ & $\begin{array}{l}\text { - Diminui a condução atra- } \\
\text { vés do sitema His-Purkinje e } \\
\text { de feixes anô-malos } \\
\text { - Inibe receptores alfa e beta } \\
\text { adrenérgicos e possui pro- } \\
\text { priedades vagolíticas e de } \\
\text { bloqueadores de canais de } \\
\text { cálcio } \\
\text { - Aumenta a duração do } \\
\text { potencial de ação em todo o } \\
\text { tecido cardíaco } \\
\text { - No nó sinusal - reduz a } \\
\text { FC, diminui a condução } \\
\text { para o nó AV e diminui a } \\
\text { resposta ventricular }\end{array}$ & $\begin{array}{l}\text { - Hipotensão arterial é o } \\
\text { principal efeito colateral } \\
\text { - Bradicardia (pode neces- } \\
\text { sitar de marca-passo) } \\
\text { - Precipita em meio básico } \\
\text { - Diminui o metabolismo da } \\
\text { digoxina e da warfarina } \\
\text { - Efeito aditivo com outras } \\
\text { medicações que prolongam } \\
\text { o QT: antiarrítmicos Classe } \\
\text { IA, fenotiazínicos, tricí- } \\
\text { clicos, tiazídicos e sotalol. }\end{array}$ \\
\hline $\begin{array}{l}\text { ATROPINA } \\
\text { Apresentação } \\
\text { - variável; } \\
\text { a mpolas de } 0,25 \\
\text { mg/ } 1 \mathrm{ml}(0,5 \text { e } 1 \mathrm{mg} \text {, } \\
\text { na dependência do } \\
\text { serviço). }\end{array}$ & $\begin{array}{l}\text { Assistolia } \\
\text { AESP com ritmos bra- } \\
\text { dicárdicos (FC }<60 \\
\text { bpm) }\end{array}$ & $\begin{array}{l}\text { - PCR - } 1 \mathrm{mg} \text { a cada } 3 \text { a } \\
5 \text { min } \\
\text { - Fora da PCR - } 0,5 \text { a } 1 \mathrm{mg} \\
\text { a cada } 3 \text { a } 5 \mathrm{~min} \\
\text { Dose máxima } \\
\text { - } 0,03 \text { a } 0,04 \mathrm{mg} / \mathrm{kg}\end{array}$ & $\begin{array}{l}\text { - Aumenta a FC por ace- } \\
\text { lerar a descarga do NSA e } \\
\text { o bloqueio vagal } \\
\text { - Efeito dromotrópico }\end{array}$ & $\begin{array}{l}\text { - Não utilizar doses me- } \\
\text { nores do que o recome- } \\
\text { ndado (efeito paradoxal) } \\
\text { - Taquicardia, TV e extra- } \\
\text { sístoles } \\
\text { - Cuidado em pacientes } \\
\text { isquêmicos e em pacientes } \\
\text { com alto grau de bloqueio } \\
\text { AV } \\
\text { - Não atua em corações } \\
\text { transplantados }\end{array}$ \\
\hline $\begin{array}{l}\text { BICARBONATO } \\
\text { DE SÓDIO } \\
\text { Apresentação } \\
\text { - soluções de bicar- } \\
\text { bonato de sódio } \\
8,4 \% \text { - } 1 \mathrm{mEq} / \mathrm{ml}\end{array}$ & $\begin{array}{l}\text { Assistolia ou AESP } \\
\text { - S O M EN TE EM } \\
\text { S ITU A Ç Õ ES DE } \\
\text { RESSUSCITAÇÃO } \\
\text { PROLONGADA OU } \\
\text { EM QUE SE S US- } \\
\text { PEITE DE: INTO- } \\
\text { X I C A Ç Ã O P O R } \\
\text { ANTIDEPRESSIVO } \\
\text { T R I C Í L L I C O S , } \\
\text { A C I D O S E M E - } \\
\text { TABÓLICA OU HI- } \\
\text { PERPOTASSEMIA }\end{array}$ & $\begin{array}{l}\text { Ataque } \\
\text { - } 1 \mathrm{mEq} / \mathrm{kg} \text { ev inicialmen- } \\
\text { te metade dessa dose a } \\
\text { cada } 10 \mathrm{~min} \text { posterior- } \\
\text { mente }\end{array}$ & $\begin{array}{l}\text { - Nas fases iniciais da PCR, } \\
\text { a massagem e ventilação } \\
\text { eficazes são suficientes para } \\
\text { controlar a acidose meta- } \\
\text { bólica. } \\
\text { - Suplementação de bicar- } \\
\text { bonato nas fases iniciais } \\
\text { pode acarretar compli- } \\
\text { cações } \\
\text { - Nas fases tardias da PCR } \\
\text { (> } 10 \text { min) ou nos casos em } \\
\text { que suspeite de acidose } \\
\text { prévia, o bicarbonato pode } \\
\text { ser benéfico. }\end{array}$ & $\begin{array}{l}\text { - Complicações - acidose } \\
\text { do líquido cerebroespinal; } \\
\text { hipernatremia e hiperos- } \\
\text { molaridade. } \\
\text { - Cuidados na adminis- } \\
\text { tração - administrar em via } \\
\text { separada de aminas vaso- } \\
\text { ativas ou adrenalina, pois } \\
\text { inativa tais substâncias. }\end{array}$ \\
\hline
\end{tabular}




\begin{tabular}{|c|c|c|c|c|}
\hline $\begin{array}{l}\text { LIDOCAÍNA } \\
\text { Apresentação } \\
\text { - } 100 \mathrm{mg} / 5 \mathrm{ml}\end{array}$ & FV/TV sem pulso & $\begin{array}{l}\text { - TV e stá ve } 1 \text { - } 1 \text { a } 1,5 \\
\mathrm{mg} / \mathrm{kg} \text { ev em bolus; repetir } \\
0,5 \text { a } 0,75 \mathrm{mg} / \mathrm{kg} \text { a cada } 3 \\
\text { a } 5 \mathrm{~min} \text {, se não houver } \\
\text { reversão. } \\
\text { - FV/TV sem pulso - } 1 \text { a } \\
1,5 \mathrm{mg} / \mathrm{kg} \text { ev em bolus; } \\
\text { repetir } 1 \text { a } 1,5 \mathrm{mg} / \mathrm{kg} \text { a cada } \\
3 \text { a } 5 \mathrm{~min} \text {, se não houver } \\
\text { reversão. Pode ser utilizada } \\
\text { por cânula endotraqueal } \\
\text { (dobro da dose ev). } \\
\text { Dose máxima - } 3 \mathrm{mg} / \mathrm{kg} \text {. } \\
\text { Manutenção } \\
\text { - } 1 \text { a } 4 \text { mg/minuto. }\end{array}$ & $\begin{array}{l}\text { - Inibe o influxo de sódio } \\
\text { através dos canais rápidos } \\
\text { das células miocárdicas. } \\
\text { - Diminui a condução em } \\
\text { tecidos isquêmicos, com } \\
\text { menor influência no tecido } \\
\text { normal. }\end{array}$ & $\begin{array}{l}\text { - Metabolismo diminuído em } \\
\text { pacientes com ICC, disfunção } \\
\text { hepática, choque, idade maior } \\
\text { de } 70 \text { anos, perfusão periférica } \\
\text { diminuída e uso de cimetidina } \\
\text { ou betabloqueadores. Nesses } \\
\text { pacientes, a dose de ataque é } \\
\text { a mesma, mas a de manutenção } \\
\text { deve ser diminuída à metade. } \\
\text { - Toxicidade SNC - graus } \\
\text { variados de confusão mental. } \\
\text { - Contra-indicada em pa- } \\
\text { cientes com graus avançados } \\
\text { de BAV e Síndrome de Wolf- } \\
\text { Parkinson-White. }\end{array}$ \\
\hline $\begin{array}{l}\text { MAGNÉSIO } \\
\text { Apresentação } \\
\text { - ampolas de } \\
\text { sulfato de magnésio } \\
6 \%(0,6 \mathrm{~g} / 10 \mathrm{ml}) .\end{array}$ & $\begin{array}{l}\text { - TV polimórfica, in- } \\
\text { duzida por drogas, } \\
\text { mesmo na ausência } \\
\text { de deficiência de ma- } \\
\text { gnésio. } \\
\text { - TV polimórfica, in- } \\
\text { duzida por deficiência } \\
\text { de magnésio. } \\
\text { - PCR quando distúr- } \\
\text { bio do ritmo apresen- } \\
\text { tado for sugestivo de } \\
\text { Torsades de Pointes. }\end{array}$ & $\begin{array}{l}\text { Ataque } \\
\text { - } 1 \text { a } 2 \text { gr em } 50 \text { a } 100 \mathrm{ml} \\
\text { de SG5\% em } 5 \text { a } 60 \mathrm{~min} \\
\text { (fora da PCR) ou } 1 \text { a } 2 \mathrm{~g} \\
\text { em } 10 \mathrm{ml} \text { de SG5\% em } \\
\text { bolus (na PCR). } \\
\text { Manutenção } \\
\text { - } 0,5 \text { a } 1 \text { g/hora. }\end{array}$ & $\begin{array}{l}\text { - Essencial para várias en- } \\
\text { zimas intracardíacas, que } \\
\text { atuam na condução. } \\
\text { - Deficiência implica em } \\
\text { várias anormalidades de } \\
\text { condução e automatici- } \\
\text { dade. } \\
\text { - Suprime a automatici- } \\
\text { dade miocárdica em cé- } \\
\text { lulas parcialmente despo- } \\
\text { larizadas. }\end{array}$ & $\begin{array}{l}\text { - Cuidado em pacientes emuso } \\
\text { de digital, com insuficiência } \\
\text { renal crônica, bloqueios atrio- } \\
\text { ventriculares, pré-existentes. } \\
\text { - Contra-indicações - depres- } \\
\text { são respiratória, hipocalcemia } \\
\text { e hipermagnesemia. } \\
\text { - Sinais de overdose - hipo- } \\
\text { tensão, rubor facial, bradi- } \\
\text { cardia e graus avançados de } \\
\text { BAV, depressão respiratória, } \\
\text { alteração do nível de cons- } \\
\text { ciência, diminuição dos re- } \\
\text { flexos musculares e flacidez } \\
\text { muscular. }\end{array}$ \\
\hline $\begin{array}{l}\text { PROCAINAMIDA } \\
\text { Apresentação } \\
\text { - ampolas } \\
500 \mathrm{mg} / 5 \mathrm{ml}\end{array}$ & FV/TV sem pulso & $\begin{array}{l}\text { Ataque } \\
\text { - } 20 \mathrm{mg} / \mathrm{min} \text { até: } \\
\text { resolução do distúrbio de } \\
\text { ritmo, hipotensão, } \\
\text { alargamento do QRS } \\
>50 \% \text { basal, dose máxima } \\
\text { de } 17 \mathrm{mg} / \mathrm{kg} \text { ter sido } \\
\text { administrada. } \\
\text { Manutenção } \\
\text { - } 1 \text { a } 4 \mathrm{mg} / \mathrm{min}\end{array}$ & $\begin{array}{l}\text { - Reduz condução atrial, } \\
\text { ventricular e no sistema de } \\
\text { His-Purkinge. } \\
\text { - Diminui a automaticidade. }\end{array}$ & $\begin{array}{l}\text { - Reduzir a dose de manu- } \\
\text { tenção em insuficiência he- } \\
\text { pática e renal. } \\
\text { - Contra-indicações - lúpus } \\
\text { eritematoso sistêmico; pa- } \\
\text { cientes com reação de sen- } \\
\text { sibilidade à procaína ou outros } \\
\text { anestésicos à base de ésteres; } \\
\text { QT prolongado. } \\
\text { - Interação medicamento- } \\
\text { sa - amiodarona (metabolismo } \\
\text { hepático), lidocaína (depressão } \\
\text { SNC) e colinérgicos (precipita } \\
\text { crises miastênicas em pacientes } \\
\text { com Miastenia Gravis). }\end{array}$ \\
\hline VASOPRESSINA & FV/TV sem pulso & $\begin{array}{l}\text { - } 40 \text { UI ev em bolus uma } \\
\text { única vez. }\end{array}$ & $\begin{array}{l}\text { - Aumenta a pressão de } \\
\text { perfusão. }\end{array}$ & $\begin{array}{l}\text { - Devido a sua duração pro- } \\
\text { longada, pode ser utilizada em } \\
\text { uma única dose. } \\
\text { - Mesmos cuidados reque- } \\
\text { ridos para adrenalina. }\end{array}$ \\
\hline
\end{tabular}


Deve-se dar preferência, sempre, para acesso calibroso no antebraço, para a infusão de medicação endovenosa. $\mathrm{O}$ acesso venoso pode ser difícil na PCR. Em tais situações, pode-se utilizar a via endotraqueal. Apenas as seguintes medicações podem ser aplicadas pela cânula orotraqueal: Naloxone, Epinefrina, Lidocaína e Atropina ("quem faz medicação na cânula, faz NELA"). Para que a medicação seja absorvida pela via endotraqueal, deve atingir o plano dos alvéolos, que pode ser obtido pela aplicação da medicação através de um cateter inserido através do tubo endotraqueal, o mais profundamente possível, seguido da infusão de $10 \mathrm{ml}$ de solução salina, e da insuflação pulmonar com dispositivo bolsa-valva-máscara, por duas a quatro vezes. Isso garante que a medicação seja dispersa para os alvéolos em aerossol e possa ser absorvida.

A via intra-óssea também pode ser utilizada, embora seja mais freqüente o seu uso em atendimentos pediátricos.

\section{1- Vasoconstritores}

Existem evidências, mostrando que o uso de vasoconstritores, no contexto da PCR, implique em uma série de efeitos potencialmente benéficos, embora, até o momento, não se tenha comprovado melhora da sobrevida. O principal efeito que se atribui a tais medicamentos é o aumento da pressão de perfusão coronariana - PPC (diferença entre a pressão arterial sistólica e a pressão do átrio direito) ${ }^{(5,6)}$. Na PCR, a PPC decai lentamente nos primeiros quatro minutos de PCR e, posteriormente, sofre uma queda mais pronunciada. Quando os valores caem abaixo de $20 \mathrm{mmHg}$, mesmo que o paciente seja submetido à desfibrilação e haja reversão para um ritmo mais organizado, não se consegue recuperação hemodinâmica. Acredita-se que isso seja ocasionado pelo aumento do retorno venoso para o lado direito do coração e desvio do septo interventricular para a esquerda, impedindo a distensão das fibras miocárdicas esquerdas e o mecanismo de Frank-Starling. As manobras de SBV e o uso de vasoconstritores, embora incapazes de elevar a PPC para valores pré-PCR, são capazes de eleva-los acima de $20 \mathrm{mmHg}$.

Atualmente, a adrenalina e a vasopressina são utilizadas na PCR, como vasoconstritores. A vasopressina está liberada para uso nas situações de FV/TV Sem Pulso e especula-se a indicação de seu uso para as outras modalidades de PCR. Tem como atrativo meia-vida mais prolongada, que permite uma única injeção durante a PCR e sofre menor inativação com o estado de acidose, presente em PCR prolongada. Quando comparada à adrenalina, não mostrou superioridade na redução de mortalidade ${ }^{(7)}$.

\section{2- Antiarrítmicos}

Os antiarrítmicos devem ser utilizados como facilitadores, ou seja, podem ser utilizados na PCR por FV/TV sem pulso, para potencializar o efeito do desfibrilador. Como medicações isoladas, não há evidências de que sejam capazes de converter o ritmo para sinusal.

Todos os antiarrítmicos são, potencialmente, próarrítmicos. Esse efeito aumenta à medida em que se associam os antiarrítmicos. Tal constatação tem ganhado força e norteou a redução da ênfase dada ao uso dessas medicações nas atuais diretrizes de ressuscitação.

Com base nas duas premissas citadas, atualmente, recomenda-se a escolha de um único antiarrítmico, para ser utilizado na PCR. Após esgotada a dose dessa medicação, não se deve associar um novo antiarrítmico.

Dentre os antiarrítmicos utilizados, a amiodarona vem ganhando espaço, apresentando, atualmente, o maior número de evidências de que seja útil nesse contexto $^{(8,9)}$.

\section{3- Outras medicações}

O bicarbonato de sódio pode ser utilizado apenas nas situações de Assistolia/AESP, quando se suspeitar de acidose pré-existente, hiperpotassemia conhecida ou intoxicações por tricíclicos.

Fora de tais situações, o bicarbonato de sódio tem lugar apenas nas situações de PCR prolongada, porém sua eficácia é duvidosa.

A atropina tem lugar, também, nas situações de Assistolia/AESP (na AESP apenas quando o ritmo no monitor apresentar frequiência menor que $60 \mathrm{bpm}$ ).

\section{7- CUIDADOS PÓS-RESSUSCITAÇÃO}

$\mathrm{O}$ período que se segue à reversão de parada cardiorrespiratória (PCR) pode envolver uma gama de apresentações, incluindo desde o paciente que recupera a consciência imediatamente, até quadros de choque de difícil manuseio. A forma com que se apresentam os casos depende da duração, da etiologia e das condições de atendimento.

Os sobreviventes podem se apresentar com recuperação da consciência e estabilidade hemodinâmi- 
ca, mas, geralmente, apresentam hipotensão e choque num período inicial que varia de 12 a 24 h após a parada cardíaca. Nessa fase inicial, cerca de metade dos pacientes morre. Segue-se período variável de um a três dias em que se observa melhora do padrão hemodinâmico, podendo cursar com restabelecimento das funções. Um fator limitante para a resolução do quadro, nesse período, passa a ser o comprometimento de outros órgãos, como fígado, rins e pâncreas, que podem apresentar disfunção, com evolução para Síndrome de Disfunção dos Múltiplos Órgãos (SDMO). Os pacientes que assim se apresentam, geralmente, cursam com septicemia, devido à quebra da "barreira intestinal", apresentando prognóstico reservado ${ }^{(10)}$.

Os cuidados pós-ressuscitação irão, portanto, variar de acordo com a forma com que se apresenta o paciente e a fase em que ele se encontra.

\section{1- Medidas Gerais}

\subsection{1- Cuidados com o paciente revertido de PCR fora do ambiente hospitalar - Suporte Bá- sico de Vida.}

Caso não estejam disponíveis condições para suporte avançado de vida, reavalie o paciente, utilizando o ABCD secundário, descrito mais à frente.

Em paciente com pulso, mas sem respiração espontânea ou com respiração inadequada, execute respiração boca-a-boca até que o suporte avançado de vida esteja disponível para garantir uma via aérea definitiva.

Se o paciente apresentar ventilação e circulação espontâneas efetivas, garanta a permeabilidade da via aérea. Uma das maneiras de fazê-lo é colocar o paciente em posição de resgate ${ }^{(11)}$. A posição de resgate visa permitir que a via aérea fique desobstruída, ao impedir que a língua se desloque posteriormente e ao favorecer a drenagem de secreções. Há vários tipos de posicionamento da vítima, que podem ser implementados desde que não impliquem em riscos para o paciente (por exemplo, se há suspeita de trauma cervical, a mobilização pode implicar em dano medular). O posicionamento da vítima em posição intermediária, entre o decúbito dorsal e o decúbito lateral (o mais próximo possível do decúbito lateral), é recomendado pelas novas diretrizes. Reavalie, constantemente (a cada minuto), o paciente, quanto à persistência de ventilação e circulação. A posição de resgate deve permitir o fácil reposicionamento em decúbito dorsal, caso surja, novamente, parada cardíaca. Mude o paciente de posição (inverta do lado do decúbito) a cada 30 min, para evitar danos à circulação do membro superior, que está posicionado inferiormente, apoiando a cabeça.

Nos casos em que se dispuser de DEA, mantenha o aparelho ligado e os eletrodos aderidos ao tórax do paciente, mesmo após o retorno da circulação espontânea. $\mathrm{O}$ aparelho executará a análise do ritmo a cada minuto, auxiliando na monitorização, até que o suporte avançado de vida esteja disponível.

\subsection{2- Providencie o transporte do paciente para Unidade de Terapia Intensiva}

Inúmeros fatores podem contribuir para a instabilização do paciente previamente estável, dentre eles: a interrupção de infusão de drogas vasoativas ou anti-arrítmicas, deslocamento do tubo orotraqueal, ocorrência de alterações do ritmo cardíaco com repercussões hemodinâmicas, entre outras.

Idealmente, o transporte deve contar com, pelo menos, dois profissionais treinados, sendo um deles habilitado em SAVC. Ventilador de transporte, acoplado ao leito, se o paciente estiver sedado e intubado. Oximetria de pulso permite detectar hipoxemia, cuja principal causa é a ventilação inadequada, sendo fator desencadeante de arritmias potencialmente letais. Medicações de urgência e material de suporte básico e avançado de vida devem fazer parte do equipamento levado em cada transporte.

\section{A- Vias aéreas}

A.1- Garanta o posicionamento adequado do tubo endotraqueal

Cuidados redobrados são recomendados na obtenção e na manutenção da via aérea ${ }^{(12)}$. Após a reversão da PCR, está indicada a utilização de capnógrafos ou capnômetros, para a checagem contínua do adequado posicionamento do tubo endotraqueal. A utilização de isolados critérios clínicos pode não ser garantia adequada, principalmente ao se considerar transporte desses pacientes, quer extra-hospitalar (do local do evento até o hospital), quer intra-hospitalar (das dependências da emergência ou enfermaria até o ambiente de terapia intensiva).

Fixe o tubo endotraqueal, garantindo que ele não seja deslocado com a movimentação do paciente. Dispositivos comerciais para a fixação adequada do tubo estão se tornando disponíveis, e as evidências apontam que seu uso possa ser superior ao dos dispositivos comumente empregados. 
A.2 - Garanta a permeabilidade do tubo endotraqueal

Cuide para que o paciente esteja adequadamente sedado, evitando "brigas" com o respirador. Os pacientes semiconscientes podem causar obstrução do tubo endotraqueal ao tentar morder o mesmo.

Parte do cuidado com o tubo implica na aspiração de secreções que podem causar obstrução por rolhas. Considere, sempre, que tais pacientes podem apresentar alterações de perfusão cerebral e que o processo de aspiração pode implicar em aumento da pressão intracraniana e conseqüente agravamento da condição. Ao realizar a aspiração, respeite os cuidados de hiperventilação prévia e não exceda o tempo preconizado $^{(13)}$.

\section{B - Respiração}

B.1 - Forneça oxigênio de acordo com as necessidades do paciente

No atendimento imediato, forneça oxigênio a $100 \%$

Realize a monitorização contínua, com o uso de oximetria de pulso, se os níveis pressóricos permitirem, e titule o fornecimento de oxigênio.

B.2 - Avalie a presença de complicações decorrentes do atendimento da parada

Descarte a ocorrência de pneumotórax ou hemotórax por fratura de arcos costais, conseqüentes à compressão torácica externa; barotrauma ou intubação seletiva.

\section{B.3 - Evite a hiperventilação}

Geralmente, a acidose ocorrida durante a PCR apresenta resolução espontânea, uma vez que a circulação e a respiração tenham sido restabelecidas. Não é necessário hiperventilação para se obter o objetivo. Mantenha a freqüência das ventilações entre 12 a 15 respirações por minuto ${ }^{(12)}$.

A hiperventilação pode agravar o estado de hipoperfusão cerebral, que ocorre no pós-ressuscitação, ao induzir vasoconstricção cerebral. Outro fator agravante encontra-se no potencial para o desenvolvimento de auto PEEP (Positive End-Expiratory Pressure Pressão Positiva Expiratória Final), com aumento da pressão venosa cerebral e conseqüente elevação da pressão intracraniana, implicando em maior dano cerebral $^{(10)}$. Mantenha os níveis de PCO2 dentro dos parâmetros normais. Utilize capnógrafos ou capnômetros, para reduzir a necessidade de coleta de gasometrias. Utilize a hiperventilação apenas se houver indicação neurológica específica (herniação cerebral) ou nos casos de hipertensão pulmonar, quando pode haver benefício.

\section{C - Circulação}

\section{C.1 - Estabilização da Pressão Arterial}

Embora, como ressaltado acima, a existência de pressão arterial, em níveis considerados clinicamente aceitáveis, não implique em perfusão adequada de todos os órgãos, o restabelecimento e a manutenção da pressão arterial são pontos-chave em se garantir perfusão cerebral adequada. Nos pacientes muito hipotensos, monitorize a pressão arterial de forma invasiva, pois os equipamentos eletrônicos de medida não invasiva da pressão arterial apresentam freqüentes erros de leitura ${ }^{(14)}$. Embora controversa, a utilização de monitorização invasiva das pressões intracavitárias e do débito cardíaco através de cateter de SwanGanz pode ser necessária. A correção dos quadros de hipotensão pode envolver reposição volêmica, para garantir pressão de enchimento adequada e, caso não haja resposta, a utilização de aminas vasoativas.

O conhecimento do manuseio dos estados de choque pós-PCR advém em sua maior parte, de outros estados de choque, pela carência de estudos com esse grupo de pacientes. A utilização do algoritmo de Choque/Edema Agudo de Pulmão das Diretrizes de Ressuscitação permite manuseio adequado ${ }^{(13,15)}$ e será revisto em outra seção desta revista.

\section{C.2- Sondagem Vesical de Demora}

O débito urinário horário é bom parâmetro para a avaliação da perfusão renal. A diurese horária pode indicar a necessidade de medidas mais agressivas para elevação da pressão arterial. Oligúria constitui-se num achado freqüente nesses pacientes. Procure determinar a causa, corrigindo, se necessário, a volemia através da infusão de líquidos. A utilização de diuréticos de alça (furosemida) deve ser realizada apenas após a garantia de que a oligúria não se deve a estado de hipoperfusão renal, decorrente de hipovolemia, relativa ou absoluta ${ }^{(14)}$. Não existem evidências que justifiquem o uso de dopamina em baixas doses (1 a $3 \mu \mathrm{g} / \mathrm{kg} / \mathrm{min}$ ) para aumentar a perfusão renal. O uso indiscriminado de dopamina, nessas doses, também pode ser deletério ${ }^{(16,17)}$. Várias complicações, incluindo taquicardias, arritmias cardíacas, isquemia 
miocárdica, aumento do "shunt" intrapulmonar com piora dos padrões respiratórios, além da piora da perfusão intestinal, podem estar associadas ao seu uso.

Evite o uso de drogas nefrotóxicas.

\section{C.3 - Tonometria Gástrica}

A monitorização do gradiente gástrico/sistêmico de PCO2 tem sido apontada como recurso que pode avaliar o estado de hipoperfusão esplâncnico.

C.4 - Monitorização Eletrocardiográfica Contínua

Mantenha o paciente monitorizado para detecção precoce de arritmias. Garanta que esteja recebendo infusão contínua de antiarrítmico, para prevenir novos eventos arrítmicos, caso, durante o atendimento da PCR, tenha sido documentada a ocorrência de fibrilação ou taquicardia ventricular. Taquiarritmias supraventriculares pós-ressuscitação são comuns no período de reversão imediato, devido ao nível circulante das catecolaminas utilizadas durante a reversão da parada. Geralmente, são autolimitadas e não necessitam de tratamento ${ }^{(13)}$.

A presença de bradiarritmias no período pósressuscitação deve direcionar o socorrista para uma revisão do $\mathrm{ABCD}$ secundário, garantindo que não existam falhas no suporte ventilatório principalmente. Caso a bradicardia persista após essa revisão considere o tratamento segundo o algoritmo de bradicardia, ${ }^{(18)}$ descrito no capítulo de Distúrbios do Ritmo Cardíaco.

\section{C.5 - Acesso Venoso}

Mantenha acesso venoso adequado às necessidades de reposição volêmica, considerando acesso central para monitorização invasiva de pressões intracavitárias.

Troque as punções venosas, realizadas sem assepsia, durante o atendimento da parada cardíaca, por punções assépticas.

Mantenha infusão de soluções fisiológicas a $0,9 \%$, reservando as soluções glicosadas para pacientes com hipoglicemia comprovada. Hiperglicemia, no período PCR, pode potencializar o dano para o sistema nervoso central.

\section{D - Diagnóstico}

D.1- Procurar estabelecer a causa da parada cardíaca

Simultaneamente aos cuidados estabelecidos acima e tão logo se consiga a estabilização dos níveis hemodinâmicos, inicie a busca da etiologia da parada cardíaca. $\mathrm{O}$ ritmo apresentado durante o atendimento da parada pode ser o ponto de partida para a busca da causa.

Fibrilação Ventricular/Taquicardia Ventricular sem Pulso (FV/TV) - Um elevado contingente dos pacientes que se apresentaram em ritmo de fibrilação ou taquicardia ventricular, durante a parada, são portadores de doença coronariana significativa ${ }^{(19)}$. Embora a gênese das arritmias ventriculares seja multifatorial no contexto da morte súbita, esse dado leva ao questionamento da contribuição da obstrução coronariana aguda (síndrome isquêmica aguda), nos casos de parada cardíaca, considerando-se que a presença desse fator implica em técnicas de reperfusão coronariana, como tratamento imediato. Spaulding et $\mathrm{al}^{(20)}$ submeteram à coronariografia um grupo de 84 pacientes sobreviventes de PCR fora do hospital, logo após a admissão. Foi realizada a comparação de dados clínicos e eletrocardiográficos com os dados de coronariografia, visando determinar o poder dessas variáveis no diagnóstico de síndrome isquêmica aguda. História de dor precordial, precedendo a parada cardíaca e eletrocardiograma de 12 derivações, obtido após a reversão apresentaram valor preditivo positivo e negativo de 0,67 e 0,74 isoladamente, e de 0,87 e 0,61 , quando associados, para a presença de obstrução coronariana, detectada por coronariografia, obtida imediatamente após a reversão da PCR. Aqueles pacientes que tiveram obstrução coronariana documentada, com sinais de obstrução recente (imagem sugestiva de trombo ou facilidade da corda-guia em ultrapassar a lesão) foram submetidos à angioplastia, observando-se melhora da sobrevida nos casos em que se obteve sucesso. O baixo valor preditivo negativo dos dados clínicos e eletrocardiográficos encontrado e o benefício sobre a mortalidade nos pacientes em que a angioplastia foi realizada com sucesso levou os autores a considerar a indicação de coronariografia imediatamente após a reversão da parada cardíaca naqueles pacientes em que uma causa não possa ser determinada. Algumas limitações, como o número de pacientes incluídos, impõem novos trabalhos para confirmação dessa indicação ${ }^{(21)}$. Naqueles pacientes em que se obtenha confirmação eletrocardiográfica de infarto agudo do miocárdio, a seleção de uma terapêutica de reperfusão é necessária. A massagem cardíaca externa, desde que não prolongada, está gradativamente deixando de ser considerada contra-indicação à terapia trombolítica. No entanto, a angioplastia, 
em tais pacientes, pode ser a abordagem mais segura, desde que haja equipe de hemodinâmica qualificada e disponível, e que seja realizada em tempo hábil.

Embora sua realização, no contexto agudo, imediatamente após a reversão da parada cardíaca, ainda seja discutível, a coronariografia está indicada após a estabilização dos pacientes que foram revertidos de uma parada cardíaca e que não tiveram um diagnóstico claro estabelecido ${ }^{(22)}$, pela alta prevalência de comprometimento extenso da circulação coronariana.

Aproximadamente $90 \%$ dos pacientes que apresentaram fibrilação ventricular, durante a parada cardíaca, apresentam doença cardíaca estrutural (doença coronariana ou miocardiopatia) quer de conhecimento prévio quer não. No entanto, cerca de $5 \%$ desses não apresentam doença cardíaca estrutural documentável, os chamados casos de fibrilação ventricular idiopática ${ }^{(23)}$. Tais pacientes, geralmente, são jovens, previamente hígidos, sendo a parada cardíaca a primeira manifestação da doença, e apresentam elevada taxa de recidiva se a causa não for determinada e tratada adequadamente. A investigação desses pacientes pode ser prolongada e de difícil determinação, e envolve, além da história clínica e do exame físico, a realização de exames, como: avaliação laboratorial (função tireoidiana, alcoolemia sérica, provas de atividade inflamatória, glicemia, alterações hidroeletrolíticas), ecocardiograma, testes de estresse, coronariografia, estudo eletrofisiológico e, em alguns casos, biópsia endomiocárdica, quando se suspeitar de miocardite, como causa da PCR.

Atividade Elétrica Sem Pulso (AESP) - Considere outras hipóteses, principalmente para os pacientes que apresentaram parada cardíaca em atividade elétrica sem pulso e certifique-se de que as causas que, porventura, já tenham sido identificadas, durante $o$ atendimento da parada, tenham resolução definitiva (por exemplo, providencie drenagem torácica no paciente que apresentou parada cardíaca por pneumotórax que foi drenado por agulha durante a parada). Na determinação dessas outras hipóteses, a avaliação radiológica do tórax e a avaliação laboratorial são imprescindíveis. Caso sejam determinadas alterações laboratoriais, como níveis elevados de potássio, efetue a correção.

Assistolia - A caracterização da assistolia, como ritmo terminal, numa parada cardíaca, está cada vez mais cristalizada. Os casos que têm assistolia documentada e que apresentam reversão da PCR são ra- ros, e a busca de causas deve ser a mesma dos casos de atividade elétrica sem pulso, de acordo com as novas Diretrizes de Ressuscitação ${ }^{(18)}$.

D.2 - Tente estabelecer a presença de doenças subjacentes, que possam dificultar a estabilização do paciente

Doenças subjacentes podem tanto ser a causa da parada cardíaca como podem ser fatores que dificultem a estabilização do paciente. A determinação e correção de anormalidades laboratoriais deve ser executada.

\section{2 - Cuidados Específicos}

\subsection{1- Posicionamento do Paciente}

Em decúbito dorsal, com a cabeceira elevada a $30^{\circ}$, para diminuir a pressão intracraniana.

\subsection{2 - Temperatura}

A hipertermia pode estar presente no período pós-ressuscitação e é extremamente deletéria para o sistema nervoso central. Cada $1^{\circ} \mathrm{C}$ de aumento na temperatura implica em um aumento de $8 \%$ no metabolismo cerebral. Deve ser agressivamente controla$\mathrm{da}^{(10)}$ com a utilização de antitérmicos e compressas geladas. Evidências recentes sobre o benefício da hipotermia ${ }^{(24)}$, em sobreviventes inconscientes de PCR por FV, recomendam o resfriamento dos pacientes para temperaturas entre $32^{\circ}$ e $34^{\circ} \mathrm{C}$ durante 12 a $24 \mathrm{~h}$. Os dados são promissores também para outras modalidades de PCR. Complicações documentadas com o uso de hipotermia são: aumento da viscosidade sanguínea, maior susceptibilidade à infecção e às arritmias.

\subsection{3 - Cuidados neurológicos específicos}

A ocorrência de convulsões aumenta o consumo energético cerebral e, portanto, elas devem ser agressivamente combatidas.

\subsection{4 - Sondagem gástrica}

Realize a colocação de sonda nasogástrica de demora nos pacientes inconscientes, pós-ressuscitação. Mantenha em drenagem espontânea, se os ruídos hidroaéreos intestinais estiverem ausentes, e inicie alimentação enteral tão logo haja restabelecimento dos mesmos. Considere a utilização de bloqueadores $\mathrm{H} 2$, para prevenir sangramento intestinal. 
PAZIN FILHO A; SANTOS JC; CASTRO RBP; BUENO CDF \& SCHMIDT A. Cardiac arrest. Medicina, Ribeirão Preto, 36: 163-178, apr./dec. 2003.

ABSTRACT - The principles of cardiac arrest management are reviewed with emphasis on the basic life support and the three presentation of cardiac arrest: ventricular fibrilation/ ventricular tachycardia, assystole and pulseless electrical activity. The post-resuscitation care is discussed.

UNITERMS - Heart Arrest. Cardiopulmonar Resuscitation. Ventricular Fibrillation. Postresuscitation Care.

\section{REFERÊNCIAS BIBLIOGRÁFICAS}

1 - BUNCH TJ; WHITE RD; GERSH BJ; MEVERDEN RA; HODGE DO; BALLMAN KV; HAMMIL SC; SHEN WK \& PACKER DL. Long-term outcomes of out-of-hospital cardiac arrest after successful early defibrillation. N Engl J Med 348: 26262633, 2003.

2 - EISENBERG ME \& MENGERT TJ. Cardiac resuscitation. N Engl J Med 344: 1304-1133, 2001.

3 - FADDY SC; POWELL J \& CRAIG JC. Biphasic and monophasic shocks for transthoracic defibrillation: A meta analysis of randomised controlled trials. Resuscitation 58: 9-16, 2003.

4 - CAFFREY SL; WILLOUGHBY PJ; PEPE PE \& BECKER LB. Public use of automated external defibrillators. N Engl J Med 347: 1242-1247, 2002.

5 - FRENNEAUX M. Cardiopulmonary resuscitation - some physiological considerations. Resuscitation 58: 259-265, 2003.

6 - STEEN S; LIAO Q; PIERRE L; PASKEVICIUS A \& SJOBERG T. The critical importance of minimal delay between chest compressions and subsequent defibrillation: A haemodynamic explanation. Resuscitation 58: 249-258, 2003.

7 - BIONDI-ZOCCAI GG; ABBATE A; PARISI Q; AGOSTINI P; BURZOTTA F; SANDRONI C; ZARDINI P \& BIASUCCI LM. Is vasopressin superior to adrenaline or placebo in the management of cardiac arrest? A meta-analysis. Resuscitation 59: 221-224, 2003.

8 - DORIAN P; CASS D; SCHWARTZB; COOPER R; GELAZNIKAS $R$ \& BARR A. Amiodarone as compared with lidocaine for shock-resistant ventricular fibrillation. N Engl J Med 346: 884-890, 2002.

9 - KUDENCHUK PJ; COBB LA; COPASS MK; CUMMINS RO; DOHERTY AM; FAHRENBRUCH CE; HALLSTROM AP; MURRAY WA; OLSUFKA M \& WALSH T. Amiodarone for resuscitation after out-of-hospital cardiac arrest due to ventricular fibrillation. N Engl J Med 341: 871-878, 1999.

10 - PART 6: ADVANCED CARDIOVASCULAR LIFE SUPPORT . Section 8: Postresuscitation Care. [Guidelines 2000 for Cardiopulmonary Resuscitation and Emergency Cardiovascular Care: International Consensus on Science]. Circulation 102: I-166 - I-171, 2000. Suppl. I.
11 - PART 3: ADULT BASIC LIFE SUPPORT. [Guidelines 2000 for Cardiopulmonary Resuscitation and Emergency Cardiovascular Care: International Consensus on Science]. Circulation 102: I-22 - I-59, 2000. Suppl. I.

12 - PART 6: ADVANCED CARDIOVASCULAR LIFE SUPPORT. Section 3: Adjunts for oxygenation, ventilation, and airway control. [Guidelines 2000 for Cardiopulmonary Resuscitation and Emergency Cardiovascular Care: International Consensus on Science]. Circulation 102: I-95 - I-104, 2000. Suppl. I.

13 - CUMMINS RO. Textbook of Advanced Cardiac Life Support, 1994. American Heart Association, Dallas, 1994.

14 - SOCIETY PF CRITICAL CARE MEDICINE. Fundamentos em terapia intensiva: Texto de curso. Trad. coordenada por Antonio Capone Neto e Cid Marcos N. David. 2 $2^{\mathrm{a}}$ ed. Revinter, Rio de Janeiro, 2000.

15 - PART 6: ADVANCED CARDIOVASCULAR LIFE SUPPORT. Section 6: Pharmacology II: Agents to Optimize Cardiac Output and Blood Pressure. [Guidelines 2000 for Cardiopulmonary Resuscitation and Emergency Cardiovascular Care: International Consensus on Science]. Circulation 102: I$129-\mathrm{I}-135,2000$. Suppl. I.

16 - THOMPSON BT \& COCKRILL BA. Renal-dose dopamine: A siren song? Lancet 344: 7-8, 1994.

17 - DENTON MD; CHERTOW GM \& BRADY HR. "Renal-dose" dopamine for the treatment of acute renal failure: scientific rationale, experimental studies and clinical trials. Kidney Int 49: 4-14, 1996.

18 - PART 6: ADVANCED CARDIOVASCULAR LIFE SUPPORT Section 7: Algorithm Approach to ACLS Emergencies: 7 A: Principles and practice of ACLS. [Guidelines 2000 for Cardiopulmonary Resuscitation and Emergency Cardiovascular Care: International Consensus on Science]. Circulation 102: I-136 - I-139, 2000. Suppl. I.

19 - SRA J; DHALAA; BLANCK Z; DESHPANDE S; COOLEY R \& AKHTAR M. Sudden cardiac death. Curr Probl Cardiol 24: 461-540, 1999.

20 - SPAULDING CM; JOLY LM; ROSENBERG A; MONCHI M; WEBER SN; DHAINAUT JFA \& CARLI P. Immediate coronary angiography in survivors of out-of-hospital cardiac arrest. $\mathbf{N}$ Engl J Med 336:1629-1633, 1997. 
21 - ZAHGER D. Immediate coronary angiography in survivors of out-of-hospital cardiac arrest. N Engl J Med 337:1321-1322, 1997.

22 - SCALON PJ; FAXON DP; AUDETAM; CARABELLO B; DEHMER GJ; EAGLE KA; LEGAKO RD; LEON DF; MURRAY JÁ; NISSEN SE; PEPINE CJ; WATSON RM; RITCHIE JL; GIBBONS RJ; CHEITLIN MD; GARDNER TJ; GARSON A Jr; RUSSELL RO Jr; RYAN TJ \& SMITH SC Jr. ACC/AHA guidelines for coronary angiography: A report of the American College of Cardiology/American Heart Association Task Force on Practice Guidelines (Committee on Coronary Angiography). J Am Coll Cardiol 33:1756-1824, 1999.
23 - UCARE/IVF-US STEERING COMMITTEES. Survivors of outof-hospital cardiac arrest with apparently normal heart. Need for definition and standardized clinical evaluation. Circulation 95: 265-272, 1997.

24 - NOLAN JP; MORLEY PT; HOEK TL; HICKEY RW \& ADVANCEMENT LIFE SUPPORT TASK FORCE. Therapeutic hypothermia after cardiac arrest. An advisory statement by the Advancement Life Support Task Force of the International Liaison Committee on Resuscitation. Resuscitation 57: 231-235, 2003. 